\title{
Reversal of statin-induced memory dysfunction by co-enzyme Q I0: a case report
}

This article was published in the following Dove Press journal:

Vascular Health and Risk Management

6 November 2015

Number of times this article has been viewed

\section{Basil N Okeahialam}

Cardiology Sub-Unit I, Department of Medicine, Jos University Teaching Hospital, Jos, Nigeria

Video abstract

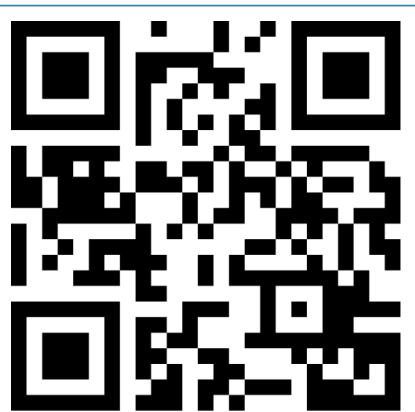

Point your SmartPhone at the code above. If you have a QR code reader the video abstract will appear. Or use: http://youtu.be/6H2atAo-Imo
Correspondence: Basil N Okeahialam Jos University Teaching Hospital, PMB 2076 (3 Murtala Muhammed Way) Jos, 93000 I, Plateau State, Nigeria

Tel +23480 5l49 927।

Email basokeam@yahoo.com
Abstract: Statins are useful in the armamentarium of the clinician dealing with dyslipidemia, which increases cardiovascular morbi-mortality in hypertensive and diabetic patients among others. Dyslipidemia commonly exists as a comorbidity factor in the development of atherosclerotic cardiovascular disease. Use of statins is however associated with side effects which at times are so disabling as to interfere with activities of daily living. There are various ways of dealing with this, including use of more water-soluble varieties, intermittent dosing, or use of statin alternatives. Of late, use of co-enzyme Q10 has become acceptable for the muscle side effects. Only one report of any benefit on the rarely reported memory side effect was encountered by the author in the search of English medical literature. This is a report of a documented case of a Nigerian woman with history of statin intolerance in this case, memory dysfunction despite persisting dyslipidemia comorbidity. Her memory dysfunction side effect which interfered with activities of daily living and background muscle pain cleared when coenzyme Q10 was administered alongside low dose statin. Her lipid profile normalized and has remained normal. It is being recommended for use when statin side effects (muscle- and memory-related) impair quality of life and leave patient at dyslipidemia-induced cardiovascular morbi-mortality.

Keywords: statin, memory dysfunction, co-enzyme Q10, improvement

\section{Introduction}

Memory dysfunction, though said to be a rare occurrence, ${ }^{1}$ is a recognized side effect of statin therapy. ${ }^{2}$ Only one case has been reported in the medical literature from Nigeria. ${ }^{3}$ It tends to greatly limit normal functioning in an individual so afflicted, hence its potential for impairing quality of life. This side effect like others usually results in discontinuation of the culprit drug. ${ }^{4}$ In dyslipidemia, this results in persistence of cardiovascular morbidity in the individual(s) in question.

In the case of skeletal muscle side effect, co-enzyme Q10 (CoE Q10) has been reported to have an ameliorating effect, ${ }^{5}$ as well as vitamin D replacement. ${ }^{6}$ Only one report of such amelioration on the part of CoE Q10 for statin-induced memory dysfunction was encountered in a wide search of medical literature. ${ }^{7}$ No such report was encountered from sub-Saharan Africa. CoE Q10 has been used with statins in situations where the disease impairs mitochondrial bioenergetics with increased oxidative stress; as in some neurological diseases, with benefit. ${ }^{8}$ It has been shown to reverse age-related impairment in spatial learning while lowering protein oxidation, leading to the conclusion that it stands to ameliorate age-associated symptoms of cognitive deficit. ${ }^{9}$ Recently, one was compelled to try CoE Q10 supplementation in a patient previously reported ${ }^{3}$ for intolerance of statin manifesting with muscle and memory 
side effects - as her lipid profile worsened despite substitution with statin substitutes and adjuvants. ${ }^{10}$ The response was impressive. She experienced no muscle or memory side effect while on CoE Q10 supplementation and her lipid profile improved.

This case is being reported to suggest to clinicians who may encounter memory issues with statin that CoE Q10 supplementation may be worth the try.

\section{Case report}

Patient AA had been reported previously with memory dysfunction while on different statins. ${ }^{3}$ For the current report, ethical approval was not sought because the case did not meet institutional requirements and the Declaration of Helsinki was duly observed. As she remained dyslipidemic with a history of statin discontinuation, she was given fish oil in the form of Omega-3 1,000 mg daily in September 2011. This did not necessarily improve her memory. With her lipid profile standing at total cholesterol (TC) $-5.2 \mathrm{mmol} / \mathrm{L}$, high density lipoprotein cholesterol (HDL-C) - $1.0 \mathrm{mmol} / \mathrm{L}$, low density lipoprotein cholesterol (LDL-C) - $3.0 \mathrm{mmol} / \mathrm{L}$, and triglyceride (TG) - $0.9 \mathrm{mmol} / \mathrm{L}$ in December 2011, she was given fenofibrate $160 \mathrm{mg}$ daily. She reported to cause her muscle cramps like the statins prompting self-discontinuation and a repeat lipid profile. We could not assay for creatinine kinase, but her liver and kidneys were normal in structure and function. With lipid profile standing at TC $5.7 \mathrm{mmol} / \mathrm{L}, \mathrm{HDL}-\mathrm{C}-1.0 \mathrm{mmol} / \mathrm{L}, \mathrm{LDL}-\mathrm{C}-3.2 \mathrm{mmol} / \mathrm{L}$, and TG $-1.1 \mathrm{mmol} / \mathrm{L}$ in January 2012, she was advised to persevere on fenofibrate, because the symptom of muscle cramp was mild. Attempting to do this brought in addition vertigo and unsteady gait. Reporting this, she was asked to stop the drug and put on Stugeron brand of cinnarizine (15 mg twice daily) which controlled the symptoms.

When her lipid profile was repeated late in June 2012, it stood at TC $-6.0 \mathrm{mmol} / \mathrm{L}, \mathrm{HDL}-\mathrm{C}-1.4 \mathrm{mmol} / \mathrm{L}$, LDL-C -3.1 $\mathrm{mmol} / \mathrm{L}$, and TG $-1.3 \mathrm{mmol} / \mathrm{L}$. She was consequently put on niacin $100 \mathrm{mg}$ daily. With this, there was no complaint, but the lipid profile worsened over time to levels of TC $-6.1 \mathrm{mmol} / \mathrm{L}$, HDL-C $-0.9 \mathrm{mmol} / \mathrm{L}$, and TG $-1.3 \mathrm{mmol} / \mathrm{L}$ when repeated in February 2013. This prompted the addition of Lipitor brand of atorvastatin to the $100 \mathrm{mg}$ daily of niacin. No sooner had she started this combination did disabling and unsettling memory lapses recur. Lipitor was dropped as a result. She was then asked to take a combination of low dose statin and CoE Q10 when she came in September 2013. Out of fear and frustration, she did not but returned in November 2013 with a lipid profile of TC - $6.1 \mathrm{mmol} / \mathrm{L}$, HDL-C - $1.2 \mathrm{mmol} / \mathrm{L}$, LDL-C
$-4.2 \mathrm{mmol} / \mathrm{L}$, and TG $-0.9 \mathrm{mmol} / \mathrm{L}$. She was counseled and her fears dispelled. She then accepted to use rosuvastatin $5 \mathrm{mg}$ at night and CoE Q10 capsules $100 \mathrm{mg}$ daily. She returned in February 2014 to report that she had neither memory dysfunction nor muscle cramp, and her lipid profile now stood at TC $-3.7 \mathrm{mmol} / \mathrm{L}, \mathrm{HDL}-\mathrm{C}-1.0 \mathrm{mmol} / \mathrm{L}, \mathrm{LDL}-\mathrm{C}-1.7$ $\mathrm{mmol} / \mathrm{L}$, and $\mathrm{TG}-1.4 \mathrm{mmol} / \mathrm{L}$. By her last appointment in May 2014 while still on the last treatment, she still remained well regarding her memory with a lipid profile of $\mathrm{TC}-3.8$ $\mathrm{mmol} / \mathrm{L}, \mathrm{HDL}-\mathrm{C}-1.0 \mathrm{mmol} / \mathrm{L}, \mathrm{LDL}-\mathrm{C}-2.0 \mathrm{mmol} / \mathrm{L}$, and $\mathrm{TG}-0.7 \mathrm{mmol} / \mathrm{L}$ (Table 1 ).

\section{Comments}

The most common side effect reported with statins is myalgia. ${ }^{11}$ This is said to largely result from depletion of CoE Q10 caused by statins. ${ }^{12}$ Statins being HMG-CoA reductase inhibitors do this by blocking the mevalonate pathway. ${ }^{12} \mathrm{CoE}$ Q10 is an antioxidant that stabilizes the cell membrane, and as a critical cofactor in the mitochondrial energy metabolism is responsible for regenerating ATP. ${ }^{13}$ Because it is found in every single cell in the body, its level could also fall in the brain cells as statins have been shown to target several tissues. ${ }^{14}$

Supplementation of CoE Q10 in statin-treated patients with myopathy has been shown to ameliorate such pains. ${ }^{5}$ This patient suffered myopathy with several statins as reported earlier. ${ }^{3}$ She eventually developed memory dysfunction which led to their discontinuation. She did not even tolerate fenofibrate, a statin alternative recommended in the face of persisting dyslipidemia for patients intolerant of statins. ${ }^{10}$ Interestingly, on another recommended alternative niacin, she had no side effect but the lipid parameters worsened. With the morbidity consequence of mixed dyslipidemia

Table I Lipid profiles with time on various treatments

\begin{tabular}{|c|c|c|c|c|c|}
\hline Date & TC & HDL-C & LDL-C & TG & Remarks \\
\hline December & 5.2 & 1.0 & 3.0 & 0.9 & Given fenofibrate \\
\hline 2011 & & & & & 160 mg daily \\
\hline January 2012 & 5.7 & 1.0 & 3.2 & I.I & Remained on above \\
\hline June 2012 & 6.0 & 1.4 & 3.1 & 1.3 & Given niacin $100 \mathrm{mg}$ daily \\
\hline February 2013 & 6.1 & 0.9 & - & 1.3 & Remained on above \\
\hline November & 6.1 & 1.2 & 4.2 & 0.9 & Given rosuvastatin \\
\hline 2013 & & & & & and CoE QIO \\
\hline February 2014 & 3.7 & 1.0 & 1.7 & 1.4 & Remained on above \\
\hline May 2014 & 3.8 & 1.0 & 2.0 & 0.7 & $\begin{array}{l}\text { On above, no } \\
\text { muscle/memory issue }\end{array}$ \\
\hline
\end{tabular}

Notes: All values are in units of $\mathrm{mmol} / \mathrm{L}$. Fenofibrate gave mild muscle discomfort that was later followed by vertigo and ataxia. Niacin gave no side effects but did not improve lipid profile. Rosuvastatin and CoE Q 10 normalized lipid profile and did not cause any side effects.

Abbreviations: TC, total cholesterol; HDL-C, high density lipoprotein cholesterol; LDL-C, low density lipoprotein cholesterol; TG, triglyceride; CoE QI0, co-enzyme QI0. 
remaining and even worsening, she was put on low dose rosuvastatin $5 \mathrm{mg}$ with $100 \mathrm{mg}$ of CoE Q10. The choice of rosuvastatin was because of its water solubility and utilization of non-CYP3A4 metabolic pathways, which as posited in an earlier paper is a reasonable approach when statin intolerance is experienced..$^{15}$ Her frustration with statins and the persisting dyslipidemia made us not give her any chance with only stains irrespective of the type. With CoE Q10 supplementation, she experienced no muscle discomfort and her memory remained unaffected.

CoE Q10 has been reported to improve cognitive function in depressed patients, ${ }^{16}$ and in both Alzheimer's and Parkinson patients. ${ }^{17}$ It has been reported to improve statin-induced myopathy, ${ }^{5}$ as well as memory dysfunction. ${ }^{7}$ The nonappearance of both muscle and memory side effects in this patient when CoE Q10 was given with rosuvastatin albeit in low dose would tend to suggest that in her the possible depletion of CoE Q10 was affecting both muscle and brain energy metabolism. A limitation of this report is that a mini-mental state examination which would have objectively strengthened the link was not obtained.

\section{Conclusion}

Just as it is becoming acceptable to add CoE Q10 to reverse myopathy in patients on statins ${ }^{12}$ rather than on discontinuation, it may not be out of place to suggest considering $\mathrm{CoE}$ Q10 supplementation in other statin-induced side effects particularly and generally for cardiovascular diseases. As posited in a paper, ${ }^{18}$ mitochondrial oxidative defense integrity has a place in onset and severity of cardiovascular diseases. When in equilibrium such diseases are checked, but any disequilibrium results in disease manifestation. Further studies in this regard are called for, before it can become the standard of care.

\section{Disclosure}

The author reports no conflicts of interest in this work.

\section{References}

1. Rojas-Fernandez $\mathrm{CH}$, Cameron JF. Is statin associated cognitive impairment clinically relevant? A narrative review and clinical recommendations. Ann Pharmacother. 2012;46(4):549-557.

2. Padala KP, Padala PR, Potter JF. Simvastatin induced decline in cognition. Ann Pharmacother. 2006;40(10):1880-1883.

3. Okeahialam BN, Isiguzoro IO. Statin related memory dysfunction in a Nigerian woman. A case report. Curr Drug Saf. 2012;7:33-34.

4. Brucket C, Haygen G, Dejager S, Yau C, Begand M. Mild to moderate muscular symptoms with high-dosage statin therapy in hyperlipidemic patients - the PRIMO study. Cardiovasc Drugs Ther. 2005;19(6): 403-414.

5. Caso G, Kelly P, McNurlan MA, Lawson WE. Effect of co-enzyme Q10 on myopathic symptoms in patients treated with statins. Am J Cardiol. 2007;99(10):1409-1412.

6. Morley JE. The cholesterol conundrum. JAm Geriatr Soc. 2011;59(10): 1955-1956.

7. Langsjoen PH, Langsjoen JO, Langsjoen AM, Lucas LA. Treatment of statin adverse effects with supplemental co-enzyme Q10 and statin discontinuation. Biofactors. 2005;25(1-4):147-152.

8. Littarru GP, Tiano L. Clinical aspects of coenzyme Q10: an update. Curr Opin Clin Nutr Metab Care. 2005;8(6):641-646.

9. Shetty RA, Forster MJ, Sumien N. Co-enzyme Q10 supplementation reverses age-related impairment in spatial learning and lowers protein oxidation. Age (Dordo). 2013;35(5):1821-1834.

10. Sorrentino MJ. An update on statin alternatives and adjuncts. Clin Lipidol. 2012;7(6):721-730.

11. Nawarskas JJ. HMG-CoA reductase inhibitors and co-enzyme Q 10 Cardiol Rev. 2005;13(2):76-79.

12. Marcoff L, Thompson PD. The role of co-enzyme Q 10 in statin associated myopathy: a systematic review. J Am Col Cardiol. 2007;49(23): 2231-2237.

13. Wyman M, Leonard M, Morledge T. Co-enzyme Q10: a therapy for hypertension and statin induced myalgia. Clin J Med. 2010;77(7): 435-442.

14. Hargreaves IP, Duncan AJ, Heales SJ, Lend JM. The effect of HMG CoA reductase inhibitors on co-enzyme Q10: possible biochemical/ clinical implication. Drug Saf. 2005;28(8):659-676.

15. DiNicolantonio JJ. Co-Q10 and L-carnitine for statin myalgia? Expert Rev Cardiovasc Ther. 2012;10(10):1325-1333.

16. Bragin V, Chemodanova M, Dzanofarova N, Bragin I, Czerniawski JL, Aliev G. Integrated treatment approach improves cognitive function in demented and critically depressed patients. Am J Alzheimers Dis Other Demen. 2005;20(1):21-26.

17. DiMauro S, Mancuso M. Mitochondrial diseases: therapeutic approaches. Biosci Rep. 2007;27:125-137.

18. Babato JC. Have no fear, MitoQ10 is here. Hypertension. 2009;54 222-223.
Vascular Health and Risk Management

\section{Publish your work in this journal}

Vascular Health and Risk Management is an international, peerreviewed journal of therapeutics and risk management, focusing on concise rapid reporting of clinical studies on the processes involved in the maintenance of vascular health; the monitoring, prevention and treatment of vascular disease and its sequelae; and the involvement of

\section{Dovepress}

metabolic disorders, particularly diabetes. This journal is indexed on PubMed Central and MedLine. The manuscript management system is completely online and includes a very quick and fair peer-review system, which is all easy to use. Visit http://www.dovepress.com/ testimonials.php to read real quotes from published authors. 